\title{
A SUMMER FIELD GRAFTING TECHNIQUE FOR PINE ${ }^{1}$
}

\author{
By D. P. FOWLER
}

D. P. Fowler was born in Naugatuck, Connecticut, in 1932. He received a B.Sc.F. degree from the University of New Brunswick in 1955 and a M.F. degree in 1956 from the School of Forestry, Yale University. He has been employed by the Ontario Department of Lands and Forests, Division of Research, Tree Breeding Section, since 1956.

\section{ABSTRACT}

Field grafting is an important tool of tree breeders and other foresters concerned with the production of high quality seed for forestry purposes. Field grafting of many pines is carried out in the early summer during a period which is usually crowded with pollination and nursery work. This paper describes a summer grafting technique by which it is possible to successfully field graft pine species late in the growing season using current year's growth for scion and stock material.

In the Northern Temperate Zone, field grafting of pine is usually carried out in the spring and early summer using dormant scion materials. Spring and early summer is also the period when all pine crossing work must be done. This season is further crowded by nursery work, such as planting and transplanting which limits the supply of available labor. As there is no adequate control of time of flowering nor of this peak period of nursery activity, it is desirable that a suitable grafting technique be developed to prolong the field grafting season.

Field grafting of five-needle pines very early in the spring, prior to the shoot growth, has been successful at the Southern Research Station, Maple, Ontario for a number of years and has eliminated much of the conflict between grafting and breeding work with these species. Similar attempts to graft hard pines prior to the initiation of shoot growth have been unsuccessful. Field grafting of northern hard pines is successful after the shoots of the stock have started to elongate (Holst, 1956).

Johnson (1953) successfully field grafted a number of five-needle pines by cleft grafting succulent scion and stock materials. Mergen (1954) utilized succulent materials to prolong the field grafting season of slash pine ( $P$. elliotti Engelm.). Mergen (1954) and Johnson (1953) carried out their grafting work fairly early in the growing season, during the period of very active shoot elongation. Zak (1955) successfully "soft tissue". grafted several of the "southern" pines as well as eastern white pine ( $P$. strobus L.) and obtained equally good results in early spring, midsummer and late summer when grafting on young potted stock. Mergen (1954) and Zak (1955) emphasize the necessity of maintaining a high relative humidity of the air surrounding the grafts while Johnson (1953), working in the cooler climate at Massachusetts, suggested that high humidity was not necessary.

Pine crossing work is not usually completed in southern Ontario until mid or late June. At this time the shoots of the pines have completed about $90 \%$ of their growth and the needles have long since broken their sheaths and are in a state of active expansion (Rudolf, 1957).

\footnotetext{
${ }^{1}$ Received for publication March 14, 1958.
} 
For a technique to overcome the conflict between grafting and other seasonal activities, it is necessary to extend the grafting season into mid-July. In the summer of 1956 an experiment was made to determine the feasibility of grafting during this period and to find a suitable method of protecting the grafts.

\section{Materials AND Methods}

Fresh scions were collected the day they were to be grafted from a plantation of 12-year-old red pine (Pinus resinosa Ait.) at the Southern Research Station, Maple, Ontario. Two scions of the current year's growth were collected from each of 150 trees. By using scions from a large number of trees the problem of possible individual differences in grafting compatibility was reduced. All grafting was carried out on Scotch pine (Pinus sylvestris L.). The stocks, which were nine years old at the time of grafting, had previously been cut back so that they presented numerous vigorous shoots readily accessible from the ground. Grafting was carried out on the new shoots of the current season's growth. At the time of grafting the period of active height growth had ceased but winter buds had, as yet, not developed. The texture of both scions and stock at this time was semi-succulent.

The grafting method employed throughout this experiment was the cleft graft. This type of graft, though found inferior to most other common grafting techniques with dormant materials (Mergen, 1955; Zak, 1955), is admirably suited for grafting succulent or semi-succulent materials.

The grafts were made in the following manner: a vigorous shoot was chosen on the Scotch pine stock that was comparable in size to the scion which was to be grafted. This shoot was cut back to within two inches of the base. A single longitudinal cut was made down the length of this stub. The scion was prepared by removing all but the terminal one-quarter to one-half inch of needles. Longitudinal slices were removed from opposite sides of the scion in such a manner that the faces converged at a point about $1 \frac{1 / 2}{2}$ inches below the bud. The wedgeshaped scion was then placed in the longitudinal incision of the stock so that it made a good "match". The graft was then tied with rubber budding bands.

The grafts were protected in the following manner: the use of an asphalt emulsion ("Braco") was tested, as were three kinds of inner bags (polyethylene, pliofilm and glassine) and two kinds of outer "shade" bags (wet strength and double kraft). All the bag combinations were fastened with "twistems". To facilitate securing the bags tightly and thus limit loss of moisture through the tie, a small amount of cotton batting was wrapped around the stem at a place below the graft where the bags were fastened.

The experiment was initiated on July 9, 1956, and all grafting was completed by July 13 . The actual grafting was done by one man. Alternate grafts were coated with "Braco" at the place of grafting while each succeeding graft received one of the protective bag combinations in consecutive order. The series of bag combinations was repeated until 25 grafts of each combination had been completed. Grafting was carried out during the hottest part of the day (10 a.m.4 p.m.). The average maximum daily temperature during this period of grafting was $75.2^{\circ} \mathrm{F}$. and total precipitation was .39 inches."

\footnotetext{
- Data from Government of Canada, Department of Transport, Malton Weather Station.
} 
The protective coverings remained intact until September 4, 1956, at which time they were cut open to aid hardening off. It was noted at this time that both the polyethylene and the glassine bags were intact, whereas the pliofilm bags had begun to disintegrate. All protective coverings including rubber bands were removed on October 1, 1956. A final tally of graft materials was made on June $1,1957$.

A photograph of a successful graft after one growing season is presented in Figure 1.

The limited amount of grafting stock available made it necessary to graft several scions on each tree. Unfortunately this lack of stock and distribution of the stock curtailed replicating the experiment and thus limited the possibilities of analysis.

\section{RESULTS}

The results are presented in Table 1. No significant differences (Chi Square) were found between the two outer bags nor between the use or non-use of asphalt emulsion. Polyethylene and pliofilm inner bags gave significantly better results $(.01 \%$ level) than glassine. There was no significant difference between polyethylene and pliofilm. The average percent survival of the grafts protected by polyethylene or pliofilm inner bags was $78 \%$ in comparison with $35 \%$ by glassine inner bags.

In the summer of 1957 the above grafting technique was used to propagate three species of hard pine and one white pine species. The value of asphalt emulsion and polyethylene and pliofilm inner bags was again tested. Only wet strength kraft outer bags were used. Again no difference was noted between these treatments. The results of the hard pine grafting were as follows:

\begin{tabular}{llccc}
\hline \multicolumn{1}{c}{ Species } & $\begin{array}{c}\text { Stock } \\
\text { Species }\end{array}$ & $\begin{array}{c}\text { Date } \\
\text { Grafted }\end{array}$ & $\begin{array}{c}\text { Number } \\
\text { Number } \\
\text { Grafted }\end{array}$ & $\begin{array}{c}\text { Alive } \\
\text { Nov. 20, } \\
\mathbf{1 9 5 7}\end{array}$ \\
\hline P. thunbergii & $P$. mugo & July 9 & 24 & 23 \\
$P$. tabulaeformis & $P$. mugo & July 9 & 24 & 19 \\
$P$. hwangshanensis & $P$. mugo & July 9 & 24 & 23 \\
& & & -72 & -65 \\
\hline
\end{tabular}

In the white pine grafting, $P$. peuce Grizeb was grafted onto $P$. strobus $\mathbf{L}$. Pliofilm bags were found to be more satisfactory than polyethylene bags and the asphalt emulsion apparently had a detrimental effect. The results were as follows:

\begin{tabular}{|c|c|c|c|c|c|c|}
\hline Species & $\begin{array}{l}\text { Stock } \\
\text { Species }\end{array}$ & $\begin{array}{c}\text { Date } \\
\text { Grafted }\end{array}$ & $\begin{array}{l}\text { Inner } \\
\text { Bags }\end{array}$ & Asphalt & $\begin{array}{c}\text { Graft- } \\
\text { ed }\end{array}$ & $\begin{array}{c}\text { Number } \\
\text { Alive } \\
\text { Nov. 20, } \\
1957\end{array}$ \\
\hline P. peuce & $P$. strobus & July 16 & Pliofilm & Yes & 24 & 14 \\
\hline P. peuce & P. strobus & July 16 & Pliofilm & No & 25 & 25 \\
\hline$P$. peuce & P. strobus & July 16 & Polyethylene & Yes & 24 & 13 \\
\hline P. peuce & P. strobus & July 16 & Polyethylene & No & 23 & 16 \\
\hline
\end{tabular}




\section{Discussion}

The use of an asphalt emulsion, such as "Braco", offered no advantage in summer field grafting of semi-succulent materials.

Though there were no differences noted between the use of double kraft or wet strength kraft outer "shade" bags, it was found that the wet strength bags were easier to handle and to prepare and maintained their shape better in the field than the double kraft bags. The stiffer wet strength bags were also more effective in causing the pliofilm bags to disintegrate.

Polyethylene and pliofilm inner bags proved to be more satisfactory than glassine bags because they were impervious to water. Pliofilm, though not sigrificantly better than polyethylene in graft survival, was found to be easier to handle in the field, and to maintain its shape better than polyethylene. Pliofilm bags disintegrate after a period of between one and two months, especially when enclosed in the wet strength kraft "shade" bags. This breaking up of the inner bag eliminates the necessity of cutting open the bags to facilitate hardening off. Considering the above points, the most satisfactory graft protection is afforded by covering the grafts with pliofilm inner bags and wet strength kraft "shade" bags.

TABLE 1

Results of 1956 SUMMER Grafting

Date Grafted: July 9-13, 1956

\begin{tabular}{|c|c|c|c|c|c|}
\hline \multirow[b]{2}{*}{ Outer Bag } & \multirow{2}{*}{ Inner Bag } & \multirow{2}{*}{ Asphalt } & \multirow{2}{*}{ Grafted } & \multicolumn{2}{|c|}{$\begin{array}{c}\text { June } 1957 \\
\end{array}$} \\
\hline & & & & $\overline{\text { No. Alive }}$ & $\%$ Alive \\
\hline Wet strength & Glassine & No & 25 & 7 & 28 \\
\hline Wet strength & Glassine & Yes & 25 & 12 & 48 \\
\hline Wet strength & Polyethylene & No & 25 & 17 & 68 \\
\hline Wet strength & Polyethylene & Yes & 25 & 21 & 84 \\
\hline Wet strength & Pliofilm & No & 25 & 18 & 72 \\
\hline Wet strength & Pliofilm & Yes & 25 & 24 & 96 \\
\hline Double kraft & Glassine & No & 25 & 5 & 20 \\
\hline Double kraft & Glassine & Yes & 25 & 11 & 44 \\
\hline Double kraft & Polyethylene & No & 25 & 18 & 72 \\
\hline Double kraft & Polyethylene & Yes & 25 & 18 & 72 \\
\hline Double kraft & Pliofilm & No & 25 & 21 & 84 \\
\hline Double kraft & Pliofilm & Yes & 25 & 19 & 76 \\
\hline
\end{tabular}

The summer field grafting method described above could prove a valuable tool to tree breeders and others interested in the vegetative propagation of pines in the Northern Temperate Zone. The technique is relatively simple so that untrained personnel can very quickly become proficient at it and the grafting can be carried out in a season when nursery labor is usually available. One can easily complete one hundred or more grafts in a seven hour day.

Field grafting on well established stock offers at least one advantage over grafting on potted stock for such projects as the establishment of seed orchards or seed gardens. By grafting on well established stock, in the field, the possibility 
of losing valuable grafts while transplanting is eliminated. The larger stock often allows the grafting of two or more scions on one plant thus limiting the chance of total graft failure, and more fully utilizes the well established root system. It might well be possible to graft many scions into the crowns of fairly large plantation stock. In this way seed production areas could be established with relatively heavy per acre seed yields within a few years of establishment.

\section{REFERENCES}

JOHNSON, A. G. 1953. Grafting pine out of doors. In Rept. of 2nd Southern Conf. on For. Tree Improvement (Jan. 6-7, 1953). 2 pp.

MERGEN, F. 1954. Grafting succulent slash pine scions. Southeastern For. Expt. St. Research Note 59. 2 pp.

MERGEN, F. 1955. Grafting slash pine in the field and in the greenhouse. Jour. For. 53:836842.

RUDOLF, P. O. 1957. Silvicultural characteristics of red pine. U.S.D.A., F.S. L.S.F.E.S. Stztion Paper No. 44.

ZAK, B. 1955. The grafting of shortleaf and other pine species. Southeastern Forest Expt. Sta. Station Paper No. 59. 13 pp. 


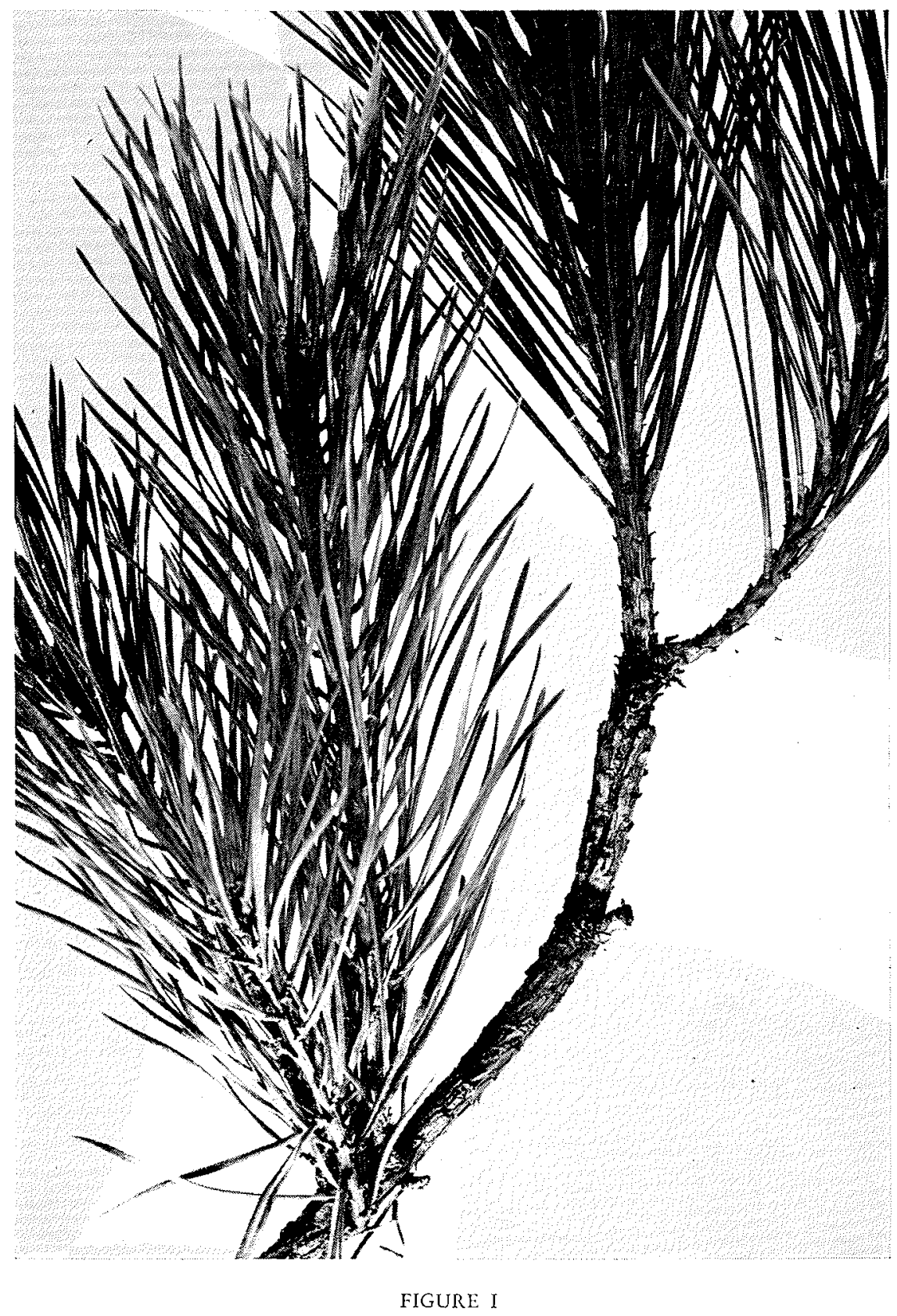

Graft of $P$. resinosa on $P$. sylvestris one growing season following grafting. 